\title{
EFEKTIFITAS LARUTAN KULIT BUAH NAGA MERAH (HYLOCEREUS POLYRHIZUS) TERHADAP JUMLAH KOLONI BAKTERI DI SALIVA
}

\author{
Sulur Joyo Sukendro ${ }^{\varpi 1}$, Nono Sulistijarso ${ }^{2}$, Endah Aryati $\mathbf{E}^{3}$, Ratnawati Hendari ${ }^{4}$
}

\begin{abstract}
ABSTRAK
Tanaman obat tradisional diantaranya Hylocereus polyrhizus atau buah naga berkulit merah. 30-35\% buah naga merah merupakan kulit namun sering kali hanya dibuang. Kulit buah naga mengandung zat warna alami dan bahan antioksidan yang bermanfaat bagi kesehatan gigi. Dalam air ludah/saliva terdapat berbagai macam jenis bakteri, dimana bakteri tersebut ada yang dapat menyebabkan kerugian didalam mulut. Tujuan penelitian ini adalah untuk mengetahui pengaruh sari kulit buah naga merah terhadap jumlah koloni bakteri di air ludah/saliva.

Metode penelitian yang digunakan adalah True Eksperiment. Desain penelitian ini adalah pre and post test design. Subyek penelitian adalah air ludah / saliva murni yang diberi larutan ekstrak kulit buah naga merah konsentrasi 25\%, 50\%, 75\% dan 100\% dengan 3 kali pengulangan. Ekstrak kulit buah naga diperoleh dengan cara dihaluskan lalu disaring. Jenis penelitian ini analitik, uji statistik yang digunakan uji Wilcoxon. Tingkat kepercayaan yang digunakan adalah 95\% atau nilai $p<0$ 0,05. Pelaksanaan penelitian di Laboratorium Mikrobiologi Jurusan Keperawatan Gigi Poltekkes Kemenkes Semarang.

Hasil penelitian adalah efektifitas konsentrasi larutan kulit buah naga merah terhadap jumlah koloni bakteri di saliva ditemukan pada konsentrasi $100 \%$ ( $p<0,05)$, dan terendah pada konsentrasi larutan $25 \%$ ( $p<0,05)$. Kandungan komposisi aktif dari kulit buah naga merah adalah adalah flavonoid. Efek antifungi dan anti bakteri yang dihasilkan oleh kulit buah naga merah pada penelitian ini disebabkan mengandung beberapa senyawa flavonoid, phenol, Vitamin C, Protein, karbohidrat dan antioksidan. Senyawa flavonoid pada buah naga merah merupakan zat warna merah dan ungu. Saran perlu dilakukan penelitian lebih lanjut dengan pemisahan zat flavonoid yang terkandung dalam kulit buah naga merah. Dan perlu penelitian lebih lanjut mengenai jenis bakteri yang efektif dihilangkan oleh kulit buah naga merah.
\end{abstract}

Kata kunci : Kulit buah Hylocereus polyrhizus, saliva, bakteri.

\begin{abstract}
Hylocereus polyrhizus or red dragon fruit is a tradisional herb. 30-35\% red dragon fruit is a rind often discarded. Rind of dragon fruit is contains natural pigments and antioxidant that are beneficial to dental health. In saliva are many types of bacteria, which can lead to harmful in the mouth Aims to determine the effect of the red dragon fruit peel extract to colonies of bacteria in saliva.

Method is true experiment, design is a pre and post test design. Subjects were saliva with a red dragon fruit peel extract concentration of 25\%, 50\%, $75 \%$ and $100 \%$ with 3 repetitions. Dragon fruit peel extract obtained by pulverized and then filtered. This type of research is analytic, statistical the Wilcoxon test. Confidence level $95 \%$ of $p$ value $<0.05$. Implementation of research in the Laboratory of Microbiology Dental Health of Nursing Departmens, Politecnique of Health Kemenkes Semarang.

Results the effectiveness of the solution concentration red dragon fruit peel extract of colonies bacteria was found at a concentration of $100 \%$ ( $p<0.05)$, and the lowest concentration of $25 \%(p<0.05)$. The active ingredient is a flavonoid. Antifungal and antibacterial effect produced by the red dragon fruit to contain several flavonoids, phenols, Vitamin C, Protein, carbohydrates and antioxidants. This compounds the red dragon fruit is a red and purple on this fruit. Suggestions for further research to be separation of flavonoids contained in the fruit. And for further research on the types of bacteria that effectively eliminated the fruit.
\end{abstract}

Keywords : Rind hylocereus polyrhizus, saliva, bacteria.

\footnotetext{
${ }_{1,2,3,4)}$ Dosen Jurusan Keperawatan Gigi Politeknik Kesehatan Kemenkes Semarang

: sulurjs@gmail.com
} 


\section{PENDAHULUAN}

Undang-Undang Kesehatan Nomor. 36 tahun 2009 pasal 9 menyatakan bahwa untuk mewujudkan derajat kesehatan yang setinggi-tingginya bagi masyarakat, diselenggarakan upaya kesehatan yang terpadu dan menyeluruh dalam bentuk upaya kesehatan perseorangan (Depkes RI, 2009). Menurut Aliya (2010) kesadaran kesehatan gigi dan mulut di negara-negara berkembang termasuk Indonesia sangat rendah. Kesehatan gigi dan mulut pada saat ini belum begitu diperhatikan karena sebagian besar kalangan masyarakat belum menyadari pentingnya kesehatan rongga mulut. Hal ini didukung data Laporan Riskesdas (Depkes RI, 2013) bahwa prevalensi nasional masalah gigi dan mulut adalah $25,9 \%$, dan kemampuan untuk mendapatkan pelayanan dari tenaga medis gigi sebesar $8,1 \%$. Sedangkan prevalensi nasional indeks kerusakan gigi (DMF-T) adalah 4,6. Hal ini disebabkan karena banyak individu yang menganggap bahwa kesehatan rongga mulut kurang penting dibandingkan masalah kesehatan tubuh lainnya yang sangat diperhatikan (Ircham, 2008).

Masalah dalam rongga mulut khususnya gigi diawali dengan adanya dental plaque atau plak. Plak adalah lapisan yang melekat pada permukaan gigi dan terdapat kuman-kuman berasal dari ludah dan mulut. Ada lebih dari 600 jenis bakteri di dalam mulut dan air ludah. Jika tidak dihilangkan secara teratur, bakteri dalam air ludah akan membentuk koloni/kumpulan. Tempat/media yang sering menjadi tempat hidupnya koloni bakteri adalah plak. Beberapa tipe bakteri dalam suatu koloni didalam plak dapat menghasilkan bahan asam yang dapat merusak karena reaksi fermentasi karbohidrat termasuk sukrosa, fruktosa, dan glukosa. Asam yang diproduksi tersebut memengaruhi mineral gigi sehingga menjadi sensitif pada $\mathrm{pH}$ rendah. Gigi akan mengalami demineralisasi dan remineralisasi. Ketika $\mathrm{pH}$ turun menjadi di bawah 5,5, proses demineralisasi menjadi lebih cepat dari remineralisasi. Hal ini menyebabkan lebih banyak mineral gigi yang luluh dan membuat lubang pada gigi. (Yuwono, 1991).

Cara yang paling mudah untuk menjaga kebersihan gigi dan mulut adalah dengan menyikat gigi. Namun pada beberapa keadaaan untuk membantu membersihkan gigi dapat menggunakan cara berkumur. Mekanisme kerja berkumur menggunakan obat kumur adalah membersihkan rongga mulut secara mekanik dan kimiawi. Selain menggunakan bahan kimia saat ini populer penggunaan bahan tradisional dibidang kesehatan. Indonesia termasuk negara di benua Asia yang banyak terdapat tumbuhan tradisional (Putri, dkk, 2011).

Buah naga (Dragon Fruit) bukan buah asli Indonesia namun saat ini sudah banyak dibudidayakan dan banyak digemari oleh masyarakat karena memiliki khasiat dan manfaat serta nilai gizi cukup tinggi. Jenis buah naga yang telah dibudi dayakan di Indonesia ada empat, antara lain Buah Naga Daging Putih (Hylocereus undatus), Buah Naga Daging Merah (Hylocereus polyrhizus), Buah Naga Daging Super Merah (Hylocereus costaricensis), dan Buah Naga Kulit Kuning Daging Putih (Selenicereus megalanthus). Bagian dari buah naga 30$35 \%$ merupakan kulit buah namun sering kali hanya dibuang sebagai sampah. Kulit buah naga hanya dianggap sebagai limbah hasil pertanian yang selama ini belum dimanfaatkan secara baik. Kulit buah naga mengandung zat warna alami antosianin dan antioksidan cukup tinggi yang juga dapat bermanfaat bagi kesehatan gigi (Kristanto, 2009, Handayani dan Rahmawati, 2012). Berdasarkan uraian tersebut maka perlu dilakukan penelitian berkaitan dengan efektifitas larutan kulit buah naga merah (Hylocereus polyrhizus) terhadap jumlah koloni bakteri di dalam ludah/saliva.

Tujuan penelitian ini adalah untuk mengetahui efektifitas larutan kulit buah naga merah (Hylocereus polyrhizus) terhadap jumlah koloni bakteri di dalam ludah/saliva; Mengetahui kandungan kulit buah naga 
merah (Hylocereus polyrhizus) yang berpengaruh terhadap jumlah koloni bakteri di dalam ludah/saliva.

Buah naga termasuk dalam kelompok tanaman kaktus atau familicuctaceaedan subfamili Hylocerenea. Dalam sub famili ini terdapat beberapa genus, sedangkan buah naga termasuk dalam genus Hylocereus. Genus ini pun terdiri dari sekitar 16 spesies, salah satunya adalah Hylocereus polyrhizus (buah naga berdaging merah) (Kristanto, 2009, Handayani dan Rahmawati, 2012).

Bagian dari buah naga $30-35 \%$ merupakan kulit buah namun seringkali hanya di buang sebagai sampah. Kulit buah naga sangat bermanfaat bagi kesehatan namun pada kenyataannya hanya dianggap sebagai limbah hasil pertanian yang selama ini belum dimanfaatkan secara baik. Kulit buah naga berdaging merah (Hylocereus polyrhizus) mengandung nutrisi yang bermanfaat. Zat yang terkandung dalam kulit buah naga berdaging merah yaitu dalam 100 g buah naga, mengandung kalori 60 kkal, protein $0,53 \mathrm{~g}$, karbohidrat $11,5 \mathrm{~g}$, serat 0,71 $\mathrm{g}$, kalsium $134,5 \mathrm{mg}$, fosfor $87 \mathrm{mg}$, zat besi 0,65mg, vitamin C 9,4mg, antosianin, antioksidan, phenol, flavonoid, protein, lemak, air, karbohidrat, abu, pentacyclictriyepene taraxast 20ene 3aol dan taraxast 12,20(30)dien 3aol, serta kandungan airnya sebanyak 90\% (Handayani dan Rahmawati, 2012). Manfaat buah naga yaitu menjaga kesehatan tulang dan gigi; mencegah diabetes mellitus; menghambat penuaan dini; mencegah kanker; menurunkan kadar kolesterol; menghaluskan kulit wajah; meningkatkan kekebalan tubuh; meningkatkan nafsu makan (Saneto, 2010).

Saliva adalah suatu cairan mulut yang kompleks dan tidak berwarna yang terdiri atas campuran sekresi dari kelenjar ludah besar dan kecil yang ada pada mukosa oral. Saliva dapat disebut juga kelenjar ludah atau kelenjar air liur. Semua kelenjar ludah mempunyai fungsi untuk membantu mencerna makanan dengan mengeluarkan suatu sekret yang disebut "saliva" (ludah atau air liur). Pembentukan kelenjar ludah dimulai pada awal kehidupan fetus $(4-12$ minggu) sebagai invaginasi epitel mulut yang akan berdiferensiasi ke dalam duktus dan jaringan asinar. Saliva terdapat sebagai lapisan setebal $0,1-0,01 \mathrm{~mm}$ yang melapisi seluruh jaringan rongga mulut. Pengeluaran air ludah pada orang dewasa berkisar antara 0,3-0,4 $\mathrm{ml} / \mathrm{menit}$ sedangkan apabila distimulasi, banyaknya air ludah normal adalah 1-2ml/menit. Menurunnya $\mathrm{pH}$ air ludah (kapasitas dapar / asam) dan jumlah air ludah yang kurang menunjukkan adanya resiko terjadinya karies yang tinggi. Dan meningkatnya $\mathrm{pH}$ air ludah (basa) akan mengakibatkan pembentukan karang gigi (Brained, 1968).

Ludah diproduksi secara berkala dan susunannya sangat tergantung pada umur, jenis kelamin, makanan saat itu, intensitas dan lamanya rangsangan, kondisi biologis, penyakit tertentu dan obat-obatan. Manusia memproduksi sebanyak 1000-1500 cc air ludah dalam 24 jam, yang umumnya terdiri dari $99,5 \%$ air dan $0,5 \%$ lagi terdiri dari garam-garam, zat organik dan zat anorganik. Unsur-unsur organik yang menyusun saliva antara lain : protein, lipida, glukosa, asam amino, amoniak, vitamin, asam lemak. Unsur-unsur anorganik yang menyusun saliva antara lain : Sodium, Kalsium, Magnesium, Bikarbonat, Khloride, Rodanida dan Thiocynate (CNS), Fosfat, Potassium. Yang memiliki konsentrasi paling tinggi dalam saliva adalah kalsium dan Natrium (Haskell dan Gayford, 1991).

Kurang lebih $80 \%$ bau mulut timbul dari dalam rongga mulut. Air ludah atau saliva memegang peranan dalam masalah bau mulut, gigi berlubang dan penyakit rongga mulut/penyakit tubuh secara keseluruhan karena air ludah melindungi gigi dan selaput lunak di rongga mulut dengan sistem buffer sehingga makanan yang terlalu asam misalnya bisa dinetralkan kembali keasamannya dan juga segala macam bakteri baik yang aerob (hidup dengan adanya udara) maupun bakteri anaerob (hidup tanpa udara) dijaga keseimbangannya. Di dalam air ludah juga terdapat antigen dan antibodi 
yang berfungsi melawan kuman dan virus yang masuk ke dalam tubuh sehingga kita sehingga tubuh tidak akan mudah terserang penyakit. Seandainya dalam keadaan normal tersebut seseorang memakai obat kumur ataupun antiseptik yang berlebihan, maka justru keseimbangan bakteri akan terganggu, bakteri-bakteri yang penting bisa menjadi mati, justru bakteri-bakteri yang merusak malah menjadi berlipat ganda sehingga timbul masalah dalam rongga mulut. Adanya bakteri akan dapat membuat sisa makanan di gigi/selaput rongga mulut terfermentasi (seperti halnya ragi), sehingga timbul racun bersifat asam yang akan membuat email menjadi rapuh (mengalami demineralisasi /mineral gigi luluh) mula-mula secara mikro dan dengan berjalannya waktu gigi akan berlubang secara kasat mata. Masalah lain, bakteri terutama bakteri anaerob (hidup tanpa udara) akan mengeluarkan gas yang mudah menguap antara lain seperti gas $\mathrm{H} 2 \mathrm{~S}$ (Hidrogen Sulfid), Metil Merkaptan dll. Gas ini menimbulkan bau mulut (Gerald dan Robert, 1981).

Ekstrak adalah zat yang dihasilkan dari ekstraksi bahan mentah secara kimiawi. Senyawa kimia yang diekstrak meliputi senyawa aromatik, minyak atsiri, ester, dan sebagainya yang kemudian menjadi bahan baku proses industri atau digunakan secara langsung oleh masyarakat. Metode ekstraksi diantaranya Penyaringan, yaitu ekstraksi berdasarkan beda jenis dan/atau ukuran partikel (Hadioetomo, 1985).

\section{METODE PENELITIAN}

Metode penelitian yang digunakan dalam penelitian ini adalah True Eksperiment. Desain penelitian yang digunakan dalam penelitian ini adalah pre test and post test design (Notoadmodjo, 2010). Subyek penelitian adalah $1 \mathrm{ml}$ air ludah / saliva yang dilarutkan dalam $10 \mathrm{ml}$ $\mathrm{Na} \mathrm{Cl}$ kemudian diberi larutan ekstrak kulit buah naga merah dengan konsentrasi $25 \%$, $50 \%$, $75 \%$ dan $100 \%$. Kemudian di ambil sejumlah $1 \mathrm{ml}$ untuk dibiakan pada media Plate Count Agar lalu dilakukan inkubasi selama 1x24 jam, Biakan dilakukan perulangan sebanyak 3 kali. Ekstrak kulit buah naga diperoleh dengan cara dihaluskan lalu disaring.

Pelaksanaan penelitian dilakukan di Laboratorium Mikrobiologi Jurusan Keperawatan Gigi Poltekkes Kemenkes Semarang. Dari data yang dikumpulkan, selanjutnya dianalisis secara statistik menggunakan uji statistik. Jenis penelitian ini adalah deskriptif analitik, uji statistik yang digunakan adalah uji Wilcoxon. Tingkat kepercayaan yang digunakan adalah $95 \%$ atau nilai $\mathrm{p}<0,05$. Semua uji diproses dengan program statistik menggunakan komputer (Sastroasmoro, 2002).

\section{HASIL DAN PEMBAHASAN}

Tabel 1. Hasil Pemeriksaan Efektivitas Konsentrasi Larutan Kulit Buah Naga Merah Terhadap Koloni Bakteri di Saliva

\begin{tabular}{|c|c|c|c|c|c|}
\hline Bakteri & $\begin{array}{c}\text { Konsentrasi } \\
\text { larutan }\end{array}$ & Perulangan & $\begin{array}{c}\text { Mean } \\
\text { Koloni / } \\
1 \mathrm{ml} \\
\text { bakteri }\end{array}$ & SD & $\mathrm{P}$ \\
\hline \multirow[t]{5}{*}{$\begin{array}{l}\text { Pre } \\
\text { test }\end{array}$} & $25 \%$ & 3 & 654 & 102 & \\
\hline & $50 \%$ & 3 & 414 & 164 & \\
\hline & $75 \%$ & 3 & 1.298 & 342 & 0,000 \\
\hline & $100 \%$ & 3 & 1.846 & 256 & \\
\hline & Kontrol & 3 & 1.560 & 426 & \\
\hline \multirow[t]{5}{*}{$\begin{array}{l}\text { Post } \\
\text { test }\end{array}$} & $25 \%$ & 3 & 338 & 74 & \\
\hline & $50 \%$ & 3 & 170 & 54 & \\
\hline & $75 \%$ & 3 & 178 & 75 & 0,000 \\
\hline & $100 \%$ & 3 & 0 & 0 & \\
\hline & Kontrol & 3 & 1.502 & 406 & \\
\hline
\end{tabular}

Pada Tabel 1 tampak secara berurutan menunjukkan hasil pemeriksaan efektivitas konsentrasi larutan kulit buah naga merah (Hylocereus polyrhizus) terhadap koloni bakteri di saliva menunjukkan bahwa pada semua konsentrasi memberikan hasil yang bermakna $(\mathrm{p}=0,00)$ dengan batas 
kemaknaan adalah $\mathrm{p}<0,05$, begitu pula dengan hasil yang ditemukan pada sebelum dan setelah perlakuan menunjukkan hasil yang bermakna $(\mathrm{p}=0,00)$. Pada Gambar 1 tampak konsentrasi yang paling efektif untuk mengurangi bakteri adalah konsentrasi larutan kulit buah naga merah $100 \%$.

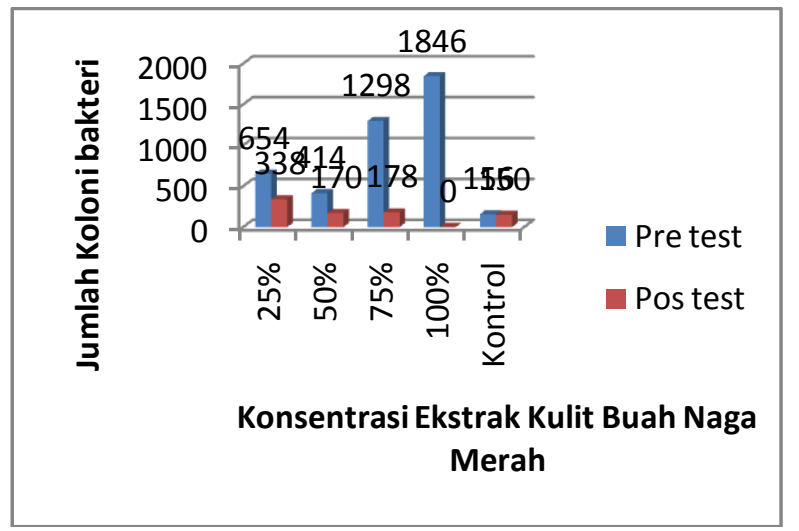

Gambar 1. Efektivitas konsentrasi larutan kulit buah naga merah terhadap jumlah koloni bakteri di saliva

Hasil dari penelitian ini menunjukkan bahwa efektivitas konsentrasi larutan kulit buah naga merah terhadap koloni bakteri di saliva ditemukan pada konsentrasi $100 \%$ $(\mathrm{p}<0,05)$, dan terendah pada konsentrasi larutan 25\% ( $<<0,05)$. Kandungan komposisi aktif dari kulit buah naga merah (Hylocereus polyrhizus) adalah adalah flavonoid. Efek antifungi dan anti bakteri yang dihasilkan oleh kulit buah naga merah (Hylocereus polyrhizus) pada penelitian ini disebabkan mengandung beberapa senyawa flavonoid, phenol, Vitamin C, Protein, karbohidrat dan antioksidan. Senyawa flavonoid adalah suatu kelompok senyawa fenol yang terbesar yang ditemukan di alam. Senyawa - senyawa ini pada buah naga merah (Hylocereus polyrhizus) merupakan zat warna merah dan ungu yang ditemukan dalam buah ini (Saneto, 2010).

Berdasarkan pada hasil temuan tersebut, efek menghambat yang rendah dari buah naga merah (Hylocereus polyrhizus) $25 \%$, disebabkan karena flavonoid yang rendah, sehingga larutan tidak cukup efektif dalam menghambat pertumbuhan bakteri. Pada ekstrak buah naga merah (Hylocereus polyrhizus) $100 \%$ mengandung flavonoid yang lebih tinggi, sehingga ia dapat lebih efektif dalam menghilangkan bakteri di saliva. Hasil ini sesuai dengan pendapat Pelczar dan chan (1988) yang menyatakan bahwa semakin tinggi konsentrasi suatu zat anti mikroorganisme akan semakin cepat pula sel mikroorganisme mati atau terhambat pertumbuhannya.

Dalam penelitian ini konsentrasi kulit buah naga merah (Hylocereus polyrhizus) $25 \%$ sudah memberikan hasil yang bermakna, hal ini dapat terjadi karena adanya saliva yang memiliki kemampuan sebagai buffer saliva. Pada larutan kulit buah naga merah (Hylocereus polyrhizus) yang paling efektif dalam menghambat pertumbuhan bakteri adalah konsentrasi $100 \%$.

\section{KESIMPULAN}

Efektifitas konsentrasi larutan kulit buah naga merah terhadap jumlah koloni bakteri di saliva ditemukan pada konsentrasi $100 \%$, dan terendah pada konsentrasi larutan $25 \%$.

\section{SARAN}

Disarankan perlu dilakukan penelitian lebih lanjut dengan pemisahan zat flavonoid yang terkandung dalam kulit buah naga merah (Hylocereus polyrhizus) yang berpengaruh dalam menghambat pertumbuhan bakteri. Perlu penelitian lebih lanjut mengenai jenis bakteri yang efektif dihilangkan oleh kulit buah naga merah (Hylocereus polyrhizus).

\section{DAFTAR PUSTAKA}

Aliya, D., 2010, Laporan Tugas Akhir, http://222.124.203.59/gdl.php?mod=br owse\&op=read\&id=jbptunikomppgdl-dinaaliyas-

21654\&q=dina\%20aliya diakses tanggal 10 November 2014. 
Brainerd, A.L., 1968, Human Histology a textbook in outline from W.B. Saunders Company, Third edition Philadelphia. London, Toronto.

Depkes RI, 2009, Undang-undang Kesehatan No.36, Jakarta.

Depkes RI., 2013, Laporan Riset Kesehatan Dasar (RISKESDAS) 2013 , Jakarta.

Gerald, I.R., Robert, C., 1981, Oral Biology.The C. V. Mosby Company.

Hadioetomo, R.S., 1985, Mikrobiologi Dasar Dalam Praktek Teknik dan Prosedur Dasar Laboratorium, Gramedia, Jakarta.

Handayani, P.A., Rahmawati, A., 2012, Pemanfaatan Kulit Buah Naga (Dragon Fruit) sebagai Bahan Pewarna Alami Makanan Pengganti Pewarna Sintetis, Jurnal Bahan Alam Terbarukan, Volume 1, No. 2, 19-24.

Haskell, R., Gayford J.J.,1991, Penyakit Mulut. Jakarta

Ircham, M., 2008, Menjaga Kesehatan Gigi dan Mulut Anak-anak dan IbuHamil, Fitramaya, Yogyakarta.

Kristanto, D., 2009, Buah Naga Pembudidayaan di Pot, Panebar Swadaya, Jakarta.

Notoadmodjo, S, 2010, Metodologi Penelitian Kesehatan, Rineka Cipta, Jakarta.

Pelczar, M.J.,Chan, E.C.S., 1988, Dasardasar mikrobiologi. Jakarta. Penerbit UI.

Putri, M.H., Herijulianti, E., Nurjannah, N., 2011, Ilmu Pencegahan Penyakit Jaringan Keras dan Jaringan Pendukung Gigi, EGC, Jakarta.
Saneto, B., 2010, Karakterisasi Kulit Buah Naga Merah (H. polyrhizus), Agrika, Malang.

Sastroasmoro, S., 2002, Dasar-dasar Metodologi Klinis, Sagung Seto, Jakarta.

Yuwono, L., 1991, Pencegahan Penyakit Mulut (Preventive Dentistry), Hipokrates, Jakarta. 